War Is All Hell 



\section{War Is All Hell}

The Nature of Evil and the Civil War

Edward J. Blum and John H. Matsui

\section{PENN}

UNIVERSITY OF PENNSYLVANIA PRESS

P H I L A DE L P H I A 
Copyright (๑ 2021 University of Pennsylvania Press

All rights reserved.

Except for brief quotations used for purposes of review or scholarly citation, none of this book may be reproduced in any form by any means without written permission from the publisher.

\author{
Published by \\ University of Pennsylvania Press \\ Philadelphia, Pennsylvania 19104-4112 \\ www.upenn.edu/pennpress
}

Printed in the United States of America

on acid-free paper

1098766543221

A catalogue record for this book is available from the Library of Congress.

ISBN 978-0-8122-5304-7 